\title{
Generating Random Pattern for Homogenization of Fiber Reinforced Composites Using Me- metic Algorithm
}

Peter Pecháč, Milan Sága, Lukáš Smetanka, Martin Močilan

University of Žilina, Univerzitná 1 Žilina 010 01, peter.pechac@fstroj.uniza.sk, milan.sagac@fstroj.uniza.sk, lukas.smetanka@fstroj.uniza.sk, martin.mocilan@fstroj.uniza.sk

The paper presents solution to random generation of fibers in composite materials for homogenization using representative volume. Randomly positioned fibers with random diameters of constrained sizes are generated within predefined representative volume, while minimal gap between fibers and volume ratio of fibers in the matrix is maintained. The problem of random generation is solved as an optimization problem using a custom memetic algorithm designed by the authors. A comparative study was performed, comparing performance of memetic algorithm and genetic algorithm.

Keywords: homogenization, composite, fibers

\section{Acknowledgement}

This work was supported by the Slovak Grant Agency VEGA 1/0795/16.

\section{References}

[1] KOPAS, P., VAŠKO, M., HANDRIK, M. (2014). Computational modeling of the microplasticization state in the nodular cast iron, (2014) Applied Mechanics and Materials, 474, pp. 285-290.

[2] JAKUBOVIČOVÁ, L., ZAVADINKA, P., JAKUBOVIČ, J. (2016). Transport duty cycle measurement of hybrid drive unit for Mixing Drum, (2016) Advances in Intelligent Systems and Computing, 393, pp. 219-224.

[3] RUSNÁKOVÁ, S., ČAPKA, A., FOJTL, L., ŽALUDEK, M., RUSNÁK, V. (2016). Technology and mold design for production of hollow carbon composite parts, (2016) Manufacturing Technology, 16 (4), pp. 799-804.

[4] ŽMINDÁK, M., PELAGIC, Z., SOUKUP, J. (2015). Analysis of fiber orientation influence to dynamic properties of composite structures, (2015) Manufacturing Technology, 15 (3), pp. 490-494.

[5] PETRU, M., MARTINEC, T., MLYNEK, J. (2016). Numerical model description of fibres winding process for new technology of winding fibres on the frames, (2016) Manufacturing Technology, 16 (4), pp. 778-785.

[6] RIECKY, D., ZMINDAK, M., PELAGIC, Z. (2014). Numerical finite element method homogenization of composite materials reinforced with fibers, Communications, 16 (3) (2014), pp. 142-147

[7] SMETANKA, L., GERLICI, J., LACK, T., PELAGIC, Z. (2014). Homogenization of fibers reinforced composite materials for simulation analysis, (2015) Manufacturing Technology, 15 (5), pp. 914-920, (2014) Komunikacie, 16 (3A), pp. 142-147.

[8] MOSCATO, P., COTTA, C. (2003). A Gentle Introduction to Memetic Algorithms, Handbook of Metaheuristics, 105-144, Springer US, 2003.

[9] YAO, X., LIU, Y., LIN, G. (1999). Evolutionary programming made faster, IEEE Transaction on Evolutionary Computation, vol.3, no.2, pp. 82-102, 1999.

[10] HANDRIK M., SÁGA M., KOPAS P. (2008). Comparation of Monte-Carlo method and white space searching (in Slo-vak), Acta Mechanica Slovaca, 2008

[11] HAGER, W., ZHANG, H. (2006). A survey of nonlinear conjugate gradient methods, Pac. J. Optim., 2 (1) (2006)

[12] CERVANTES, A. (2005). Constriction factors and Parameters, Retrieved from http://tracer.uc3m.es/tws/pso/parameters.html

[13] BANSAL, J.C., SINGH, P.K., SARASWAT, M., VERMA, A., JADON, S.S., ABRAHAM, A. (2011). Inertia Weight strategies in Particle Swarm Optimization,in Proc. IEEE Nature and Biologically Inspired Computing (NaBIC), Salamanca, 19-21, 2011.

[14] PECHÁČ, P., SÁGA, M. (2016). Controlling of Local search Methods' Parameters in Memetic Algorithms Using the Principles of Simulated Annealing, Procedia Engineering, Volume 136, 2016, Pages 70-76 